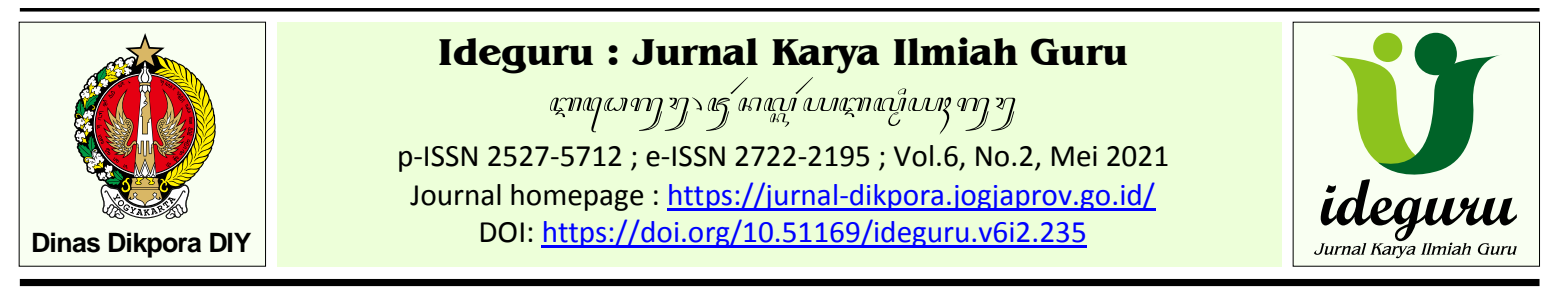

Artikel Penelitian - Naskah dikirim: 09/02/2021 - Selesai revisi: 21/03/2021 - Disetujui: 25/03/2021 - Diterbitkan: 01/05/2021

\title{
Peningkatan Keaktifan dan Hasil Belajar Materi Logika Matematika melalui Pembelajaran Kooperatif Team Game Tournament
}

\author{
Sularti \\ SMK Negeri 1 Pleret \\ larti123@yahoo.co.id
}

\begin{abstract}
Abstrak: Penelitian ini dilakukan dengan tujuan untuk mengetahui apakah penerapan model pembelajaran kooperatif TGT (Team Game Tournament) dapat meningkatkan keaktifan dan hasil belajar matematika siswa kelas XI TKJ A SMKN 1 Pleret. Jenis penelitian ini adalah penelitian tindakan kelas (PTK). Penelitian ini dilakukan bersama kolaborator yang merupakan teman sejawat. Siswa kelas XI TKJ A sebagai subyek penelitian berjumlah 34 orang. Penelitian ini dilakukan sebanyak 2 siklus, siklus pertama dengan materi pernyataan majemuk yaitu konjungsi, disjungsi, implikasi dan biimplikasi. Sedangkan siklus kedua dengan materi invers, konvers, dan kontraposisi. Instrumen yang digunakan meliputi lembar observasi dan lembar tes. Pengumpulan data dilakukan dengan observasi, dokumentasi, catatan lapangan dan tes. Teknik analisis data yang digunakan adalah analisis data kuantitatif diskriptif. Hasil penelitian menunjukkan bahwa proses pembelajaran kooperatif TGT yang terdiri dari 5 tahapan yang diterapkan pada mata pelajaran matematika dapat meningkatkan keaktifan dan hasil belajar matematika siswa. Persentase keaktifan siswa sebelum diberikan tindakan hanya $50 \%$, pada siklus I terjadi peningkatan menjadi 70,59\% dan pada siklus II meningkat menjadi $83,95 \%$. Dari tes hasil belajar diperoleh jumlah siswa yang tuntas sebelum diberikan tindakan hanya $17,65 \%$ pada siklus I terjadi peningkatan menjadi $29,41 \%$ dan meningkat menjadi $50 \%$ pada siklus II.
\end{abstract}

Kata kunci: Team Game Tournament, belajar, keaktifan.

\section{Improvement of Student Activity and Learning Achievement in Math through Cooperative Learning of Team Game Tournament}

\begin{abstract}
The aim of this study is to determine whether the application of the TGT (Team Game Tournament) cooperative learning model can increase the activeness and mathematics learning outcomes of class XI TKJ A students of SMKN 1 Pleret. This type of research is classroom action research (PTK). This research was conducted with collaborators who are colleagues. Class XI TKJ A students as research subjects totaled 34 people. This research was conducted in 2 cycles, the first cycle with compound statement material, namely conjunction, disjunction, implication and biimplication. While the second cycle with inverse, conversion, and contraposition materials. The instruments used include observation sheets and test sheets. Data collection was carried out by observation, documentation, field notes and tests. The data analysis technique used is descriptive quantitative data analysis. The results showed that the TGT cooperative learning process which consisted of 5 stages applied to mathematics subjects could increase students' learning activity and mathematics outcomes. The percentage of student activeness before being given action was only 50\%, in the first cycle there was an increase to $70.59 \%$ and in the second cycle it increased to $83.95 \%$. From the learning outcomes test, it was found that the number of students who completed before being given the action was only $17.65 \%$ in the first cycle, an increase to $29.41 \%$ and an increase to $50 \%$ in the second cycle.
\end{abstract}

Keywords: Team Game Tournament, learning, activity

\section{Pendahuluan}

Sektor pendidikan adalah sektor utama dalam kehidupan berbangsa dan bernegara. Pada sistem pendidikan Indonesia, sejak KTSP tahun 2006 dianjurkan pembelajaran berpusat pada siswa (Student Centred Learning). Dalam belajar siswa harus aktif mencari informasi baik dari buku, internet atau sumber belajar yang lain. Belajar sebagai proses memungkinkan seseorang untuk merubah perilakunya. Berbuat untuk mengubah tingkah laku disebut belajar, sehingga belajar memerlukan aktivitas. Suyono dan hariyanto (2014: 9) mengatakan bahwa aktivitas yang dilakukan untuk mendapatkan kepribadian 
yang kokoh, serta bertambahnya pengetahuan dan keterampilan disebut belajar, aktivitas ini juga akan membuat perilaku dan sikap menjadi lebih baik. Crow \& Crow dalam Hamzah B. Uno dan Nurdin Muhamad (2015: 139) mengatakan bahwa seseorang melakukan kegiatan sehingga dia mendapat pengetahuan baru, selain itu sikap dan kebiasaannya juga berubah, berarti dia sedang belajar. Burton (1984) dalam Siregar (2014: 4) mengatakan belajar merubah tingkah laku seseorang, karena terjadinya interaksi dengan lingkungannya, yang membuat dia semakin kuat menghadapi lingkungannya

Menurut Hamalik (2008: 90-91) suatu keadaan yang menjadikan siswa aktif dinamakan keaktifan belajar. Keaktifan ini menunjuk pada keaktifan mental, dan untuk mencapainya diperlukan keaktifan fisik. Menurut Hamzah B. Uno dan Nurdin Muhamad (2015: 76) salah satu cara agar pembelajaran menjadi aktif maka anak harus belajar dari pengalamannya, dan harus memecahkan masalahnya. Menurut Paul B Diedrich dalam Nanang Hanafiah dan Cucu Suhana (2010: 24) ada beberapa jenis aktivitas siswa dalam belajar yaitu kegiatan Visual, kegiatan Lisan, kegiatan mendengarkan, kegiatan menulis, kegiatan menggambar, kegiatan emosional, kegiatan motorik, dan kegiatan mental.

Di SMKN 1 Pleret terdapat permasalahan siswa tidak aktif dalam belajar. Dari pengamatan peneliti selama 3 semester, siswa kelas XI TKJ A di SMK Negeri 1 Pleret tahun pelajaran 2018/2019 keaktifan belajarnya hanya sekitar $50 \%$. Guru masih mendominasi pembelajaran matematika. Ketika guru menyampaikan materi belum semua siswa memperhatikan, ada siswa yang ramai berbicara dengan temannya, ada yang diam-diam melihat HP, ada siswa yang bermain alat tulis, dan ada yang mengantuk. Ketika siswa disuruh berdiskusi, hasilnya pun tidak optimal, beberapa siswa hanya bekerja sendiri-sendiri tidak berdiskusi dengan temannya. Sementara itu, siswa yang berkemampuan rendah hanya ramai sendiri, tidak fokus hanya mengandalkan teman sekelompoknya yang pintar. Bahkan ketika diberi soal latihan, siswa tidak segera mengerjakannya.

Sementara itu ketika diadakan ujian, nilai yang mereka peroleh belum memuaskan, masih banyak siswa yang mendapat nilai tidak tuntas. Pada tes ulangan harian dengan materi Persamaan lingkaran pada kelas XI TKJ A SMKN 1 Pleret, dari 34 siswa hanya 6 siswa atau 17,65\% siswa yang mendapat nilai tuntas, dengan KKM yang ditetapkan sekolah sebesar 75. Rifa'i (2011: 85) mengatakan bahwa seseorang yang melakukan aktifitas, setelah itu dia akan mengalami perubahan pada perilakunya, itulah yang dinamakan hasil belajar. Menurut Susanto (2013: 5) setelah anak melakukan kegiatan belajar, akan diperoleh kemampuan baru yang disebut hasil belajar. Sedangkan menurut Gagne dalam Purwanto (2014: 42) di dalam lingkungan terdapat skema yang terpola dari suatu stimulus, stimulus ini dapat mengolah, menyesuaikan, dan menghubungkan antara stimulus dengan stimulus lain, ini disebut kategori. Kemampuan menghubungkan antara kategori satu dengan kategori lain, dan yang ada di dalam kategori sendiri ini dinamakan konsep. Konsep yang dihasilkan adalah hasil belajar.

Melihat hasil belajar siswa yang jauh dari memuaskan, dan keaktifan siswa yang sangat memprihatinkan, maka perlu dicoba metode pembelajaran yang dirasa cocok dengan keadaan siswa SMKN 1 Pleret. Dengan metode pembelajaran yang sesuai diharapkan siswa dapat aktif dalam mencari ilmu dan bisa mengerjakan soal tes dengan baik. Selanjutnya Erman Suherman, dkk (2003: 201-221) mengatakan bahwa metode ceramah, metode ekspositori, penemuan inkuiri, permainan dan pemberian tugas merupakan beberapa metode yang dapat dipilih untuk pembelajaran. Sedangkan model pembelajaran dapat menggunakan model pembelajaran penemuan terbimbing, Model pembelajaran PAIKEM, PBL, pembelajaran kooperatif, dan model pembelajaran kontekstual. Menurut Joice dan Weil (dalam Prastowo, 2013: 69) bahwa seorang pengajar memerlukan rencana atau pola dalam melakukan bimbingan di dalam atau di luar kelas dalam pembelajaran, dengan rencana ini kurikulum dibentuk, bahan-bahan dirancang, begitu juga pelaksanaan pembelajaran dalam waktu yang lama. Rencana atau pola itu dinamakan model pembelajaran.

Pembelajaran kooperatif dapat memotivasi dan mendorong siswa untuk aktif belajar, di sini siswa harus bekerjasama, berdiskusi memecahkan masalah bersama. Hal ini sesuai yang dinyatakan Supriyono (2016: 196) siswa harus bekerja sama dengan teman-teman di kelompoknya dan saling bergantung dalam mencapai tujuan belajar tertentu, strategi ini dapat memotivasi belajar siswa. Siswa harus saling bekerja sama sehingga semua anggota kelompok memahami dan menguasai materi pembelajaran itulah makna pembelajaran kooperatif. Tipe kooperatif ini akan mendorong siswa menjadi aktif melaksanakan kegiatan belajar dan bekerjasama dengan teman dalam kelompoknya untuk mencapai tujuan. 
Hamdayana (2017: 145) menyatakan dalam pembelajaran kooperatif, dalam rangka mencapai tujuan bersama yang sudah ditentukan, perlu dilakukan bersama bekerjasama belajar dalam kelompoknya.

TGT termasuk model pembelajaran kooperatif. Slavin (2015: 163) mengatakan dalam TGT siswa berlomba dengan siswa dari tim lain yang kemampuan akademiknya setara, sebagai turnamen yang bersifat ilmiah, dalam TGT digunakan kuis dan penskoran. Menurut Shoimin (2014: 203) dalam TGT ada unsur permainan dan reinforcement, TGT melibatkan aktivitas seluruh siswa tanpa membedakan statusnya, TGT mudah diterapkan dan siswa dijadikan tutor sebaya. Rusman (2014: 224) mengatakan dalam TGT siswa dibagi menjadi beberapa kelompok yang terdiri dari 5 atau 6 orang. Dalam pembagian kelompok, anggota dalam satu kelompok memiliki kemampuan akademik yang berbeda, jenis kelamin, dan suku atau ras yang juga beda.

Tahapan pelaksanaan TGT yaitu sebagai berikut; 1) Presentasi kelas, pada tahap ini guru menyampaikan tujuan dan materi pembelajaran; 2) Kelompok Belajar, siswa dibagi menjadi kelompok kecil terdiri atas 4 sampai 5 orang siswa berdasarkan kriteria kemampuan akademik, jenis kelamin dan ras atau etnik; 3) Permainan, semua siswa bermain di meja turnamen masing-masing mewakili tim atau kelompoknya; 4) Turnamen, dilaksanakan tiap akhir minggu, dengan mengumpulkan point yang diperoleh anggota tim/kelompok di meja permainan; 5) Penghargaan Kelompok, siswa diberi julukan Super Team, Great Team dan Good Team sesuai skor yang diperoleh (Shoimin, 2014: 205-207).

Menurut Seviana (2013) dalam penelitiannya terjadi peningkatan hasil belajar siswa setelah menggunakan model TGT. Pada siklus II ketuntasan klasikal mencapai 83,33\%, berarti terjadi peningkatan dibandingkan pada siklus I yang hanya mencapai $47,61 \%$.

Maharjono (2016) dalam penelitiannya yang menggunakan model TGT pada pembelajaran sejarah menunjukkan adanya peningkatan prestasi belajar siswa pada mata pelajaran sejarah, dimana rata-ratanya pada siklus I hanya 74,38 meningkat menjadi 76,46 pada siklus II.Selain itu menurut Marharjono (2016), penerapan model TGT dapat meningkatkan kedisiplinan dan keberanian siswa dalam pembelajaraan. Siswa berani berinteraksi dan bertanya pada guru. Siswa yang tadinya tidak fokus dan mengantuk pada pembelajaran menjadi lebih aktif.
Sedangkan Rahayu (2017) dalam penelitiannya yang menggabungkan metode jigsaw dan TGT dalam pembelajaran Sosiologi, mengatakan bahwa dari hasil penelitian terdapat perubahan siswa menjadi lebih aktif dalam pembelajaran, tugas diserahkan tepat waktu, dan dikerjakan sesuai petunjuk guru, siswa memiliki kemandirian dan kekompakan dalam mengerjakan tugas dan mempresentasikannya, siswa juga menjadi antusias dalam mengikuti pembelajaran sosiologi. Dari hasil postes menunjukkan, siklus 1 ke siklus 2 meningkat dengan kenaikan rerata 4,66\%.

Berdasarkan beberapa penelitian diatas, peneliti merasa perlu adanya penelitian pembelajaran yang menggunakan model TGT pada pembelajaran matematika, khususnya pada materi logika matematika.

Dari uraian di atas, maka dalam penelitian ini, peneliti membuat rumusan masalah sebagai berikut; 1) Bagaimanakah implementasi model kooperatif TGT di kelas XI TKJ A SMKN 1 Pleret pada pelajaran matematika? 2) Apakah model TGT dapat meningkatkan keaktifan belajar matematika siswa XI TKJ A SMKN 1 Pleret? 3) Apakah model kooperatif TGT dapat meningkatkan hasil belajar matematika siswa kelas XI TKJ A SMKN 1 Pleret?

Tujuan dari penelitian ini, yang pertama untuk mengetahui implementasi pembelajaran kooperatif TGT di kelas XI TKJ A SMKN 1 Pleret pada pelajaran matematika. Kedua, untuk mengetahui apakah terjadi peningkatkan keaktifan belajar siswa kelas XI TKJ A melalui penerapan model kooperatif TGT pada pelajaran matematika. Ketiga, untuk mengetahui apakah terjadi peningkatkan hasil belajar matematika siswa kelas XI TKJ A melalui penerapan model kooperatif TGT.

Manfaat penelitian antara lain; bagi siswa, dapat memperoleh pengalaman pembelajaran kooperatif yang asyik dan menyenangkan sehingga diharapkan dapat memberdayakan siswa dalam belajar kelompok dan meningkatan keaktifan belajar matematika siswa. Bagi para pengajar dengan menerapkan model pembelajaran kooperatif TGT dapat menambah wawasan profesionalisme mereka guna mendorong peningkatkan keaktifan siswa dalam belajar sehingga hasil belajar juga akan meningkat. Bagi sekolah, penggunaan model kooperatif TGT yang menyenangkan, diharapkan siswa sekmakin aktif belajar sehngga prestasi semakin meningkat. 


\section{Metode Penelitian}

Penelitian yang termasuk jenis Penelitian Tindakan Kelas (PTK) ini dilakukan dalam beberapa siklus sampai target/indikator kinerja tercapai. Pertama, apabila persentase rata-rata aktivitas siswa kelas XI TKJ A dalam pembelajaran kooperatif tipe TGT mencapai $75 \%$. Kedua, apabila jumlah siswa yang tuntas hasil belajarnya mencapai $50 \%$, dengan ketuntasan belajar $\geq 75$.

Sebagai subyek penelitian yaitu 34 siswa kelas XI TKJ A. Penelitian ini dilakukan bersamaan dengan kegiatan pembelajaran di kelas, dan waktunya disesuaikan dengan jadwal pelajaran matematika di kelas XI TKJ A. Pelaksanaan dimulai pada bulan April sampai dengan Juni 2019 yang diintegrasikan dalam proses belajar mengajar. Pokok bahasan yang disampaikan pada penelitian ini adalah KD 3.22 dan KD 4.22 yaitu tentang Logika. Pada siklus I akan diberikan materi pernyataan majemuk yang berupa konjungsi, disjungsi, implikasi dan biimplikasi. Kemudian pada siklus II diberikan materi invers, konvers, dan kontraposisi dari suatu implikasi. Jika target/indikator kinerja belum tercapai maka dilaksanakan siklus III dengan materi menarik kesimpulan dari beberapa konklusi. Tempat pelaksanaan kegiatan adalah di ruang kelas XI TKJ A SMKN 1 Pleret.

Pada pelaksanaannya, tahapan pada penelitian ini ada 4 tahap di setiap siklus, yaitu: perencanaan, tindakan, pengamatan, dan refleksi. Ketika pada siklus I hasilnya belum mencapai indikator keberhasilan yang ditetapkan, maka dilaksanakan siklus II, siklus III dan seterusnya hingga indikator keberhasilan dapat tercapai dengan tahapan sama di setiap siklusnya.

Penelitian ini sekurang-kurangnya dilakukan dalam 2 siklus, tiap siklus ada 2 kali pertemuan, dan tiap pertemuan 2 jam pelajaran, adapun langkah-langkah tiap siklus adalah 1) Perencanaan, guru membuat rencana pembelajaran yang dituangkan dalam Rencana Pelaksanaan Pembelajaran (RPP), pada tahap ini guru menyiapkan instrumen pengamatan baik terhadap aktivitas guru maupun terhadap aktivitas siswa dalam proses keterlaksanaan pembelajaran. Guru juga membuat instrumen untuk mengobservasi keaktifan belajar siswa, dan media pembelajaran yang diperlukan yaitu kartu soal, kunci jawaban dan aturan permainan, menyiapkan LKS dan soal tes; 2) Pelaksanaan, RPP yang sudah dibuat yang menggunakan model TGT diterapkan dalam pembelajaran di kelas; 3) Pengamatan, guru dibantu kolaborator mengamati aktivitas guru dan aktivitas siswa dalam proses keterlaksanaan pembelajaran, serta dampak dari tindakan yang dikenakan kepada siswa selama kegiatan pembelajaran berlangsung dan 4) Refleksi, dilakukan dengan cara mendiskusikan dan menganalisis permasalahan yang muncul, kekurangan dan kelebihan yang ditemukan pada siklus awal selama pembelajaran berlangsung, dan hasilnya digunakan untuk merencanakan siklus berikutnya agar menjadi lebih baik.

Pengumpulan data dalam penelitian ini dilakukan dengan teknik observasi, pengamatan partisipatif, tes hasil belajar dan dokumentasi. Observasi dilakukan oleh kolaborator, menggunakan Lembar Observasi Siswa (LOS) dan Lembar Observasi Guru (LOG), observasi ini dilakukan guna memperoleh informasi seputar aktivitas serta keadaan guru dan siswa selama pembelajaran menggunakan model kooperatif TGT. Sedangkan peneliti melakukan pengamatan partisipatif dan dituangkan dalam Lembar Observasi Keaktifan siswa, dimana ada 6 aspek aktifitas siswa yang diamati. Sedangkan indikator aspek aktifitas siswa yang diamati dapat dilihat pada tabel 1 berikut:

Tabel 1. Indikator aspek aktivitas siswa

\begin{tabular}{ll}
\hline \multicolumn{1}{c}{$\begin{array}{c}\text { Aspek } \\
\text { aktivitas }\end{array}$} & \multicolumn{1}{c}{ Indikator } \\
\hline $\begin{array}{l}\text { Visual } \\
\text { activities }\end{array}$ & Memperhatikan penjelasan guru \\
Oral & Bertanya atau menjawab \\
activities & pertanyaan teman atau guru \\
Listening & Mendengarkan saat \\
activities & pembelajaran \\
Writing & Menulis pada saat pembelajaran \\
activities & \\
Emotional & Menaruh minat, dan antusias \\
activities & dalam pembelajaran \\
Mental & Menyelesaikan soal-soal LKS \\
activities & maupun permainan \\
\hline
\end{tabular}

Dalam rangka memperoleh data hasil belajar, guru memberikan tes hasil belajar yang dilakukan tiap akhir siklus. Beberapa bentuk dokumentasi digunakan untuk melengkapi data yang terkumpul, antara lain berupa RPP, LKS, Soal turnamen, daftar kelompok siswa, hasil pekerjaan siswa, dan foto untuk menggambarkan keadaan ruang kelas dan aktifitas siswa dalam pembelajaran.

Data yang terkumpul dalam penelitian ini di disusun, dikelompokkan, diseleksi dan dianalisis sehingga diperoleh data yang berkorelasi dengan penelitian, sehingga kita bisa memperoleh jawaban dari rumusan masalah yang kita tetapkan, lalu kita bisa menarik kesimpulan. 
Data hasil penelitian dianalisis dengan analisis deskripsi kuantitatif dengan langkahlangkah; mengelompokkan skor yang diperoleh sesuai dengan aspek yang diamati, kemudian persentase tiap aspek aktivitas siswa dihitung, kemudian menentukan rata-rata persentase keseluruhan aktivitas siswa, kemudian menentukan persentase ketuntasan hasil belajar siswa dari data tes hasil belajar siswa.

\section{Hasil dan Pembahasan Siklus I}

Siklus I terdiri dari 2 kali pertemuan. Model pembelajaran TGT yang terdiri dari lima fase di laksanakan dalam dua kali pertemuan masingmasing $2 \times 45$ menit. Pada pertemuan 1 dilaksanakan fase presentasi kelas dan fase belajar kelompok. Pada fase presentasi, guru melakukan presentasi, yakni guru memotivasi siswa untuk belajar aktif, melakukan apersepsi mengenai materi yang akan dipelajari, serta menyajikan materi. Pada fase belajar kelompok, karena kelas XI TKJA SMKN 1 Pleret ada 34 siswa, siswa dibagi menjadi 8 kelompok, yang 6 anggotanya 4 siswa dan yang 2 anggotanya 5 siswa. Kelompok dibagi secara heterogen baik dalam hal kecerdasan maupun jenis kelamin.

Pembelajaran dalam kelompok diarahkan untuk menyelesaikan soal-soal dalam LKS. Sedangkan pada pertemuan 2 dilaksanakan fase game, fase turnamen, dan fase penghargaan kelompok. Pada fase game (permainan), permainan dibagi menjadi 8 meja permainan, yang terdiri dari 2 meja permainan siswa berkemampuan akademik tinggi, 4 meja permainan siswa berkemampuan akademik sedang dan 2 meja permainan siswa berkemampuan kademik rendah. Dalam setiap meja permainan terdapat lembar aturan permainan, 1 set kartu soal, 1 set kunci jawaban dan lembar penskoran. Siswa bermain dengan anggota kelompok lain yang memiliki tingkat kemampuan akademik yang sama, sehingga semua siswa mempunyai semangat dan rasa percaya diri untuk bersaing dan menjadi yang terbaik dalam permainan di meja permainannya. setelah itu siswa diberi tes hasil belajar.

Pada fase turnamen, siswa menghitung poin yang mereka peroleh di meja permainan masingmasing. Lalu poin itu di jumlahkan dengan anggota kelompok belajarnya, lalu dirata-rata. Fase terakhir guru memberikan penghargaan kepada semua kelompok baik secara lisan (pujian) maupun secara fisik, yaitu dengan memberikan piagam penghargaan Super Team, Great Team dan Good Team sesuai skor yang diperoleh.
Hasil penelitian yang dilakukan pada siklus I memperlihatkan bahwa keaktifan belajar siswa meningkat, dibanding kondisi pra siklus, akan tetapi peningkatannya masih relatif kecil. Hal ini kemungkinan disebabkan karena siswa belum memahami model kooperatif TGT secara keseluruhan. Pada fase presentasi kelas siswa masih acuh tak acuh untuk memperhatikan penjelasan guru, dan tidak banyak siswa yang bertanya, padahal pada fase ini diharapkan siswa benar-benar memperhatikan presentasi dari guru dan mau bertanya jika ada yang belum jelas, agar mereka mampu bersaing di fase permainan. Ternyata hanya siswa yang pintar-pintar saja yang selalu bertanya, siswa belum memahami bahwa semua anggota kelompok akan bertanding di meja permainan untuk menyumbangkan poin ke kelompoknya. Karena tidak memahami hal ini maka di fase belajar kelompokpun belum semua siswa ikut aktif berdiskusi, meskipun guru selalu memotivasi agar semua siswa ikut aktif berdiskusi, siswa berkemampuan rendah tidak ikut andil dalam diskusi kelompoknya, mereka belum menyadari bahwa semua anggota kelompok ikut menyumbang poin untuk kelompoknya, dan seharusnya semua anggota kelompok memahami materi pembelajaran agar siap bertanding di meja permainan.

Pada fase game (permainan) semua siswa bertanding dengan teman yang kemampuan berpikirnya setara, siswa yang berkemampuan rendah bertanding dengan temannya yang berkemampuan rendah dengan soal-soal permainan yang tingkat kesulitannya rendah juga, begitu juga dengan siswa berkemampuan sedang, mereka bertanding dengan teman yang berkemampuan sedang dengan soal-soal permainan yang tingkat kesulitannya sedang, dan siswa berkemampuan tinggi bertanding dengan siswa berkemampuan tinggi dengan soal-soal permainan yang tingkat kesulitannya juga tinggi. Hal ini diharapkan menimbulkan keberanian dan motivasi untuk bersaing mendapatkan poin, sebelum bertanding, aktivitas bertanya mereka meningkat, baik bertanya tentang rumus maupun tentang cara mengerjakan. Mereka bertanya baik kepada guru atau temannya yang lebih pandai yang sekelompok dengannya. Di fase penghargaan kelompok mereka senang menerima piagam penghargaan, meskipun ada beberapa kelompok merasa tidak puas dengan penghargaan yang mereka dapatkan. Hal ini memotivasi mereka untuk usaha lebih keras lagi.

Selain itu pada fase permainan, guru masih membagikan alat permainan satu-persatu, pertama guru membagikan lembar aturan permainan, lalu membagikan lagi kartu soal dan 
kartu jawaban, lalu membagikan lembar untuk pencatatan poin. Padahal ada 8 meja permainan yang terdiri dari, 2 meja permainan siswa berkemampuan akademik tinggi, 4 meja permainan siswa berkemampuan akademik sedang dan 2 meja permainan siswa berkemampuan akademik rendah. hal ini juga menyita waktu permainan. Sehingga permainan yang diharapkan sebagai wahana berlatih soal sambil bermain menjadi tidak efektif, karena waktunya hanya sebentar. Selain itu anak-anak masih perlu memahami aturan permainan, karena hal itu baru pertama kali. Hal ini perlu diperbaiki pada siklus II, semua alat permainan di masing-masing meja sebaiknya dijadikan satu wadah, sehingga guru cukup sekali membagikan siswa sudah mendapatkan semua yang dibutuhkan dalam permainan secara lengkap.

Berdasarkan tes pada akhir siklus I, siswa yang mendapat nilai tuntas, juga mengalami peningkatan. Jumlah siswa yang tuntas di pra siklus yaitu pada ulangan harian pokok bahasan lingkaran, ada 6 siswa atau 17,65\% yang nilainya tuntas, dan pada siklus I ini ada 10 siswa atau $29,41 \%$ yang mendapat nilai tuntas.

Dari siklus I peneliti dan kolaborator berdiskusi menganalisis kendala-kendala yang terdapat pada siklus I tersebut, peneliti berdiskusi dengan kolaborator untuk memperbaiki proses pembelajaran tipe TGT ini pada siklus yang kedua. Pada siklus II, peneliti harus menjelaskan secara detail mengenai pembelajaran model TGT dari fase awal hingga akhir. Semua siswa harus dipahamkan bahwa pada fase game (permainan), semua siswa bertanggung jawab untuk mencari poin untuk kelompoknya, sehingga setiap siswa harus memahami materi yang sedang dipelajari agar siap untuk bertanding. Siswa juga harus diberi pengertian bahwa mereka akan bertanding dengan teman yang berkemampuan setara, sehingga mereka bersemangat dalam belajar dan berani serta siap bertanding di meja permainannya masing-masing. Semua siswa juga harus ikut aktif dalam mendiskusikan LKS di kelompoknya, karena semua soal di permainan bermuara pada LKS tersebut. Selain itu aturan permainan dan aturan penskoran juga harus dipahamkan pada siswa dengan benar agar penggunaan waktu bisa efektif, sehingga siswa bisa mengerjakan banyak soal pada fase permainan.

\section{Siklus II}

Pada siklus II, dilakukan perbaikan pembelajaran dengan mengacu pada kondisi siklus I yang sudah didiskusikan dengan kolabolator. Guru menjelaskan kembali fase-fase dalam pembelajaran TGT kepada siswa. Guru juga memberi informasi tentang pentingnya kerjasama karena semua anggota kelompok, bertanggung jawab terhadap poin yang diperoleh kelompoknya. Guru menyuruh siswa untuk memahami betul aturan-aturan dalam permainan, selain itu guru sudah menyiapkan semua yang dibutuhkan dalam permainan yaitu, lembar aturan permainan, kartu soal dan kartu jawaban, dan lembar untuk pencatatan poin, semua ditempatkan dalam satu wadah untuk tiap-tiap meja pertandingan. Guru tinggal membagikan satu wadah untuk satu meja, dan itu sudah berisi lengkap seperangkat alat untuk permainan. Guru juga sudah mengumumkan peserta game (permainan) di masing-masing meja permainan pada pertemuan pertama siklus II, sehingga pada pertemuan kedua di siklus II, semua siswa langsung menempatkan diri ke meja permainan mereka masing-masing. Dari siklus II, diperoleh data, terjadi peningkatan aktivitas belajar siswa diberbagai aspek dibandingkan pada siklus I.

Pelaksanaan tindakan pada siklus I dan II, diperoleh data aktivitas siswa di berbagai aspek mengalami peningkatan pada siklus II, sebagaimana diperlihatkan pada tabel 2 berikut:

Tabel 2. Data aktifitas siswa pada siklus I dan siklus II

\begin{tabular}{|c|c|c|c|}
\hline \multirow{2}{*}{$\begin{array}{c}\text { Aspek } \\
\text { Aktifitas }\end{array}$} & \multicolumn{3}{|c|}{ Perbandingan } \\
\hline & Siklus I & Siklus II & Kenaikan \\
\hline $\begin{array}{l}\text { Visual } \\
\text { activities }\end{array}$ & $68,75 \%$ & $85,29 \%$ & $16,55 \%$ \\
\hline $\begin{array}{l}\text { Oral } \\
\text { activities }\end{array}$ & $74,27 \%$ & $84,56 \%$ & $10,29 \%$ \\
\hline $\begin{array}{l}\text { Listening } \\
\text { activities }\end{array}$ & $72,80 \%$ & $84,56 \%$ & $11,76 \%$ \\
\hline $\begin{array}{l}\text { Writing } \\
\text { activities }\end{array}$ & $73,16 \%$ & 85 66\% & $12,50 \%$ \\
\hline $\begin{array}{l}\text { Emotional } \\
\text { activities }\end{array}$ & $66,55 \%$ & $80,15 \%$ & $13,60 \%$ \\
\hline $\begin{array}{l}\text { Mental } \\
\text { activities }\end{array}$ & $68,02 \%$ & $83,46 \%$ & $15,44 \%$ \\
\hline $\begin{array}{l}\text { Rerata } \\
\text { keaktifan }\end{array}$ & $70,59 \%$ & $83,95 \%$ & $13,36 \%$ \\
\hline
\end{tabular}

Pada tabel 2 dapat dilihat pada siklus II terjadi kenaikan aktivitas siswa di berbagai aspek aktivitas. Pada fase presentasi kelas, siswa mendengarkan dan memperhatikan penjelasan guru, mereka juga mau menulis hal-hal penting dari materi yang dipelajari, mereka mulai menyadari bahwa semua anggota kelompok bertanggung jawab untuk menyumbangkan poin dalam turnamen nanti. Begitu juga ketika fase belajar kelompok, mereka antusias untuk mengerjakan dan mendiskusikan LKS yang 
diberikan, anggota kelompok saling bertanya dan saling menjawab cara mengerjakan soal yang ada di LKS, siswa yang berkemampuan rendah, yang biasanya tidak aktif dalam diskusi dan berbincang sendiri dengan temannya, mau bertanya kepada teman sekelompoknya yang lebih pandai. Terjadi kerjasama dan kekompakan di setiap kelompok belajar, dan mereka berusaha mandiri mengerjakan latihan soal untuk persiapan menghadapi lawan di permainan. Hal ini sesuai penelitian Rahayu (2017) yang berjudul meningkatkan prestasi belajar sosiologi dengan metode jigsaw dan team game tournament, hasil penelitian menunjukkan siswa menjadi memiliki kemandirian dan kekompakan dalam mengerjakan tugas. Sementara itu siswa yang pandai yang biasanya egois mengerjakan LKS sendiri, mau mengajari teman sekelompoknya yang berkemampuan rendah dan sedang, ia bertindak sebagai tutor sebaya tanpa diprintah guru. Shoimin (2014: 203) dalam TGT ada unsur permainan dan reinforcement, TGT melibatkan aktivitas seluruh siswa tanpa membedakan statusnya, TGT mudah diterapkan dan siswa dijadikan tutor sebaya. Siswa mau membuat catatan penting dari LKS yang mereka kerjakan. Siswa menjadi lebih aktif, mereka berusaha mempersiapkan diri menghadapi game (permainan) pada hari berikutnya. Hal ini sesuai pendapat Erman Suherman, dkk (2003: 216-217) yang menyatakan bahwa permainan dalam pengajaran matematika adalah sesuatu yang menggembirakan dan dapat memicu siswa untuk aktif dalam pembelajaran, ini juga dapat meningkatkan ketrampilan, penanaman konsep, pemahaman, dan pemantapannya.

Pada fase game (permainan), semua siswa baik yang berkemampuan rendah, sedang, maupun yang berkemampuan tinggi antusias menuju ke meja permainan masing-masing, karena mereka akan bermain dengan lawan yang setara. Sebagaimana yang dikatakan Slavin (2015: 163) bahwa dalam TGT siswa berlomba dengan siswa dari tim lain yang kemampuan akademiknya setara, sebagai turnamen akademik, TGT menggunakan kuis-kuis dan sistem skor. Baik di meja permainan siswa berkemampuan rendah, berkemampuan sedang maupun di meja permainan siswa berkemampuan tinggi, terjadi permainan serius yang kadang-kadang disertai gelak tawa mereka ketika ada siswa yang mendapat soal lebih sulit dari sebelumnya, atau ada siswa yang menjawab salah karena kurang teliti. Dalam diri siswa timbul keberanian dalam permainan karena lawan mereka mempunyai kemampuan setara dengannya, selain itu siswa juga lebih disiplin dan lebih aktif. Hal ini sesuai dengan hasil penelitian Marharjono (2016) yang mengatakan bahwa pembelajaran menggunakan model TGT, selain dapat meningkatkan kedisiplianan siswa juga membuat siswa menjadi lebih berani dan aktif. Pada fase turnamen, mereka antusias membawa poin yang mereka peroleh di meja permainan untuk digabung dengan poin temannya yang sekelompok.

Pada tabel 2, juga bisa dilihat rata-rata keaktifan siswa, pada siklus I adalah 70,59\%, ini berarti meningkat dibandingkan dengan keaktifan siswa pada pra siklus yang hanya $50 \%$. Keaktifan siswa pada siklus II menjadi 83,95\%. Peningkatan keaktifan siswa ini disajikan dalam gambar 1 berikut.

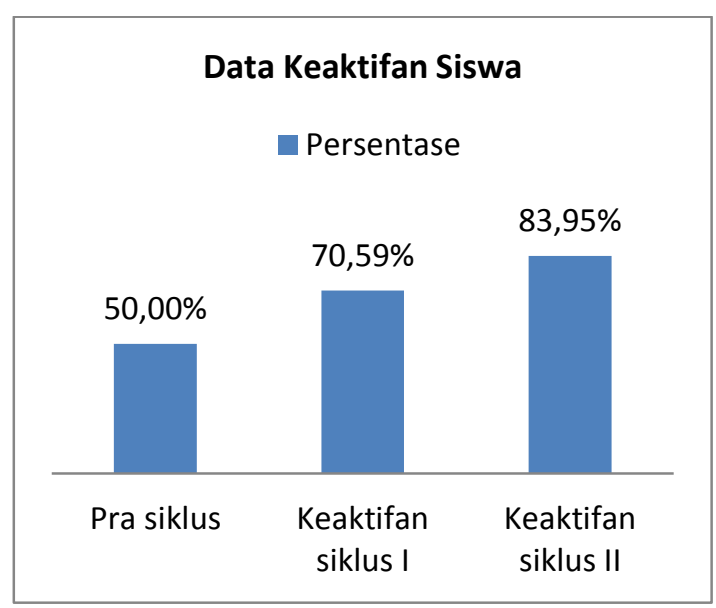

Gambar 1. Grafik peningkatan keaktifan siswa

Pada penelitian ini, tiap akhir siklus siswa diberi tes. Dari hasil tes kita peroleh data jumlah siswa yang mendapat nilai tuntas bertambah, sehingga persentasenya juga meningkat. Data pertambahan jumlah siswa yang mendapat nilai tuntas tersebut dapat dilihat pada tabel 3 berikut:

Tabel 3. Data tes hasil belajar siswa

\begin{tabular}{lcc}
\multicolumn{1}{c}{ Data } & $\begin{array}{c}\text { Jumlah Siswa } \\
\text { Tuntas }\end{array}$ & Persentase \\
\hline Pra Siklus & 6 & $17,65 \%$ \\
Siklus I & 10 & $29,41 \%$ \\
Siklus II & 17 & $50 \%$ \\
\hline
\end{tabular}

Penggunaan model TGT dalam pembelajaran, membuat siswa belajar dalam kelompok kecil, ada tutor sebaya, sehingga mereka termotivasi dan lebih semangat dalam mempelajari materi, sehingga ketika diberi soal tes, mereka lebih siap. Jadi wajar jika nilai mereka menjadi lebih baik, dan jumlah siswa yang nilainya tuntas menjadi bertambah. Apalagi ketika pada siklus II, peneliti memperbaiki proses pembelajaran TGT yang dilakukan sesuai dengan masukkan dan hasil diskusi dengan kolaborator. Hasilnya menjadi lebih baik lagi dan jumlah siswa 
yang nilainya tuntas bertambah lagi. Sejalan dengan pendapat tersebut, Seviana (2013) dalam penelitiannya terjadi peningkatan hasil belajar matematika siswa pada materi penjumlahan pecahan setelah menggunakan model TGT. Pada siklus II ketuntasan klasikal mencapai 83,33\%, berarti terjadi peningkatan dibandingkan pada siklus I yang hanya mencapai $47,61 \%$.

\section{Simpulan dan Saran}

Dari penelitian ini dapat ditarik kesimpulan bahwa Implementasi pembelajaran kooperatif TGT di kelas XI TKJA SMKN 1 Pleret berjalan dengan baik. Lima tahapan pembelajaran TGT dilaksanakan dalam 2 pertemuan. Pada pertemuan I dilakukan tahapan presentasi kelas dan belajar kelompok, sedangkan pada pertemuan II dilakukan game, turnamen dan penghargaan kelompok.

Berdasarkan analisis data pada siklus I dan II, diperoleh kesimpulan bahwa keaktifan belajar matematika mengalami peningkatan setelah diterapkan model TGT. Tingkat keaktifan siswa yang semula 50\%, meningkat menjadi 70,59\% pada siklus I, setelah diadakan koreksi dan perbaikan pada proses pembelajaran, keaktifan meningkat lagi menjadi 83,95\% pada siklus II.

Berdasarkan analisis data hasil belajar siswa. Persentase siswa yang mendapat nilai tuntas sebelum menggunakan model TGT hanya $17,65 \%$, persentase ini meningkat menjadi $29,41 \%$ pada siklus I, dan pada siklus II persentasenya menjadi $50 \%$.

Peneliti mempunyai saran, bahwa pembelajaran kooperatif TGT mengandung unsur permainan sehingga menyenangkan dan menantang untuk siswa, jadi model ini dapat dijadikan referensi dalam melaksanakan pembelajaran di kelas, pembelajaran ini dapat merangsang siswa untuk aktif belajar. Sekolah perlu memberikan dukungan dengan menyediakan fasilitas untuk kegiatan ini, seperti pengembangan LKS dan kartu-kartu permainan. Guru perlu mengembangan soal-soal turnamen, untuk masing-masing tingkat kesulitan perlu disesuaikan dengan kemampuan siswa, karena akan membuat siswa lebih tertarik. Aturan permainan dalam pembelajaran ini juga dapat dikembangkan sesuai kondisi siswa, sehingga siswa tertarik pada pembelajaran dan tertarik untuk belajar.

\section{Daftar Pustaka}

Hamalik, Oemar. (2003). Proses Belajar Mengajar. Jakarta: Bumi Aksara.

Hamdayana, Jumanta. (2017). Metodologi Pengajaran. Jakarta: bumi Aksara.
Hanafiah, Nanang dan Cucu Suhana. (2010). Konsep Strategi Pembelajaran. Bandung: Refika Aditama

Marharjono. (2016). Peningkatan Kedisiplinan dan Prestasi Belajar Sejarah Melalui Pembelajaran Kooperatif Tipe Teams Games Tournament (TGT) SMA Negeri 1 Sewon. Ideguru: Jurnal Karya Ilmiah Guru, 1(2), 113.

Prastowo, Andi. (2013). Pengembangan Bahan Ajar Tematik. Yogyakarta: Diva Press.

Purwanto. (2014). Evaluasi Hasil Belajar. Yogyakarta: Pustaka Pelajar.

Rahayu, Siti. (2017). Meningkatkan Prestasi Belajar Sosiologi Dengan Metode Jigsaw dan Team Game Tournament. Ideguru: Ideguru: Jurnal Karya Ilmiah Guru, 2(1), 54-62.

Rifa'i, Achmad dan Catharina Tri Anni. (2011). Psikologi Pendidikan. Semarang: UNNES Press.

Rusman. (2014). Model-model Pembelajaran. Bandung: PT Raja Grafindo Persada.

Seviana, Silvi W. (2013). Model Pembelajaran Kooperatif Tipe TGT untuk Meningkatkan Hasil Belajar Matematika Materi Penjumlahan Pecahan pada Siswa di Sekolah Dasar. Jurnal Penelitian Pendidikan Guru Sekolah Dasar. Vol 1, No 7 (2013).

Shoimin, Aris. (2014). Model pembelajaran Inovatif dalam Kurikulum 2013. Yogyakarta: Ar-Ruzz Media.

Siregar, Eveline dan Hartini Nara. (2014). Teori Belajar dan Pembelajaran. Bogor: Ghalia Indonesia.

Slavin, Robert E. (2015). Cooperatif Learning. Bandung: Nusa Media.

Suherman, Erman dkk. (2003). Strategi Pembelajaran Matematika Kontenporer. Bandung: Jurusan Pendidikan Matematika FMIPA Universitas Pendidikan Indonesia.

Supriyono, Agus. (2016). Model-Model Pembelajaran Emansipatoris. Yogyakarta: Pustaka Pelajar.

Susanto, Ahmad. (2013). Teori Belajar dan Pembelaran di Sekolah Dasar. Jakarta: Kencana Prenada Media Group.

Suyono dan hariyanto. (2014). Belajar dan Pembelajaran. Bandung: Remaja Rosdakarya.

Uno, Hamzah B. dan Nurdin Muhamad. (2015). Belajar dengan Pendekatan PAILKEM: Pembelajaran Aktif, Inovatif, Lingkungan, kreatif, Efektif Menarik. Jakarta: Bumi Aksara. 